\title{
ANALYSIS OF SMARTPHONE APPLICATION MASTERY IN DISTANCE LEARNING FOR DEAF CHILDREN IN SECONDARY SCHOOL
}

\author{
Hudzaifah ${ }^{1}$, Muhammad Akhyar ${ }^{2}$, Siti S Fadhilah ${ }^{3}$ \\ ${ }^{123}$ University of Sebelas Maret Surakarta \\ Jl. Ir. Sutami No.36, Kentingan, Kec. Jebres,Surakarta City, Central Java 57126 \\ hudzaifah.lodji@gmail.com makhaliya@yahoo.com nfadh.sant@gmail.com
}

\begin{abstract}
Distance learning is a learning model that is applied as one of the policies of the world government in the field of education to break the chain of the spread of the covid-19 virus. Many problems occur during distance learning, including in special education, one of which is deaf children, where deaf children have barriers in communicating but must follow learning without meeting in person in the classroom. This study aims to find out what information technology is most mastered by deaf children as a means of supporting distance learning. This research was conducted on deaf children at the high school level in extraordinary schools that during the Covid-19 pandemic the school implemented an online learning system. This study uses descriptive analysis with the questionnaire filling method. Data collection is done by disseminating questionnaires containing questions related to the mastery of applications on smartphones aimed at deaf children. Furthermore, the data is analyzed using inductive and thematic analytics. Dai this research can be known that from the use of Whatsapp application as a means of communication used to receive distance learning materials is $94.74 \%$, Zoom meeting application mastery rate $0.00 \%$, then Youtube application mastery level in receiving information $100.00 \%$. And the most preferred time for deaf children to learn is free, which is $65.79 \%$. So it can be concluded that the smartphone application that is most mastered by deaf children in high school in learning and receiving information is a Youtube application and the preferred time for deaf children in learning is free or unspecified.
\end{abstract}

Keywords: Mastery of Smartphone Applications; Deaf Children; Distance Learning

Abstrak: Pembelajaran jarak jauh merupakan model pembelajaran yang diimplementasikan sebagai salah satu kebijakan pemerintah pada bidang pendidikan untuk memutus mata rantai penyebaran virus Covid-19. Banyak permasalahan yang terjadi selama pembelajaran jarak jauh, termasuk dalam pendidikan khusus, salah satunya adalah anak tunarungu, di mana anak tunarungu memiliki hambatan dalam berkomunikasi namun mereka harus mengikuti pembelajaran tanpa bertemu lansung di dalam kelas. Penelitian ini bertujuan untuk mengetahui teknologi informasi apa yang paling dikuasai oleh anak tunarungu sebagai sarana penunjang pembelajaran jarak jauh. Penelitian ini dilakukan pada anak tunarungu tingkat SMA di sekolah luar biasa yang pada masa pandemic Covid-19 sekolah tersebut menerapkan sistem pembelajaran online. Penelitian ini menggunakan analisis deskriptik dengan metode pengisian kuesioner. Pengumpulan data dilakukan dengan menyebarkan kuesioner berisi pertanyaan terkait penguasaan aplikasi smartphone yang ditujukan untuk anak tunarungu. Selanjutnya, data dianalisis menggunakan analisis induktif dan tematik. Dari penelitian ini dapat diketahui bahwa penggunaan Aplikasi Whatsapp sebagai alat komunikasi yang digunakan untuk menerima materi pembelajaran jarak jauh

146|J P D, p-IS S N : $2252-8156$, e - I S S N : $2579-3993$ 
adalah 94,74\%, tingkat penguasaan aplikasi Zoom meeting adalah 0,00\%, kemudian tingkat penguasaan aplikasi Youtube dalam menerima informasi adalah 100,00\%. Dan waktu yang paling disukai anak tunarungu untuk belajar adalah bebas, yaitu $65,79 \%$. Sehingga dapat disimpulkan bahwa aplikasi smartphone yang paling banyak dikuasai oleh anak tunarungu tingkat SMA dalam belajar dan menerima informasi adalah aplikasi Youtube dan waktu yang disukai anak tunarungu dalam belajar adalah bebas atau tidak ditentukan.

Kata Kunci: Penguasaan Aplikasi Smartphone, Anak-anak Tunarungu, Pembelajaran Jarak Jauh

Sumber: ICEHoS - International Conference on Education, Humanities, and Social Science

$\mathrm{T}$ o this day, the threat of the Covid-19 pandemic to the world is still relatively high, this can be seen from the increasing number of confirmed cases of infection and the high death rate (Zili et al., 2021). The impact of this pandemic is felt hamper on all regions of the world and all sectors of life, including education, so that restrictions on community activities are still applied in some countries with red zones, including some regions in Indonesia. The temporary closure of educational activities is still being carried out in most countries in the world to stop the transmission of the virus (Abidah et al., 2020). Unesco recorded in 2020 (Viner et al., 2020) stated that about 107 countries closed institutions due to the Covid-19 pandemic and projected that the closure of these educational institutions impacted more than $90 \%$ of the world's child population.

As one of the steps to stop the spread of Covid-19 and also uphold education, most countries in the world since 2019 have made an emergency policy to continue to carry out educational activities by changing the education system face-to-face with the distance education system (Salama et al., 2020) Of course, the temporary suspension of face-to-face learning activities in schools that previously used manual methods shifted into distance learning activities supported by the online system. Distance learning is a learning that is done where the class teacher delivers material without meeting directly with students in one room or class (Prawiyogi et al., 2020).

Basically distance learning is facilitated with the internet. Where the form of distance learning is divided into two types, namely synchronous and asynchronous. Synchronous learning uses online video or other applications that allow students and teachers to interact 
directly, while asynchronous forms are forms of learning indirectly or at different times, this form of learning uses a selflearning approach such as lesson materials designed in such a way that it can be delivered through email facilities or other similar facilities (Ogbonna et al., 2019).

Based on previous research, there are several problems and challenges in the implementation of distance learning. To achieve success in the implementation of distance learning in education should consider aspects of understanding technology, finance, institutional, educators, and student barriers (Al-Balas et al., 2020). And in research conducted by early childhood education lecturers on online learning, there are many challenges, including network and connectivity issues.

Another obstacle is the lack of response from students (Diningrat et al., 2020). The implementation of distance learning requires the availability of infrastructure (Beneke, 2020). One of the infrastructure needed is the availability of communication tools and also internet networks.

To achieve a good quality of online learning in Indonesia there is still much to prepare, especially concerning children or students. Such research conducted by (Putri et al., 2020) in some elementary schools found that there are obstacles experienced by students in following distance learning, among others, limited socialization, lack of attention to students with special needs, lack of discipline of learning at home, lack of technological skills, and higher internet needs. The obstacles faced by teachers are the selection of methods in the delivery of learning by the wide scope of the curriculum, lack of technological skills, limited time to transfer offline materials to online, as well as a lack of communication between teachers, parents, and also principals in monitoring learning development and learning activities.

Like other regular schools, learning activities in children with special needs also experience obstacles and even more variety. Basically, children with special needs are children who need more attention but must be enforced just like other regular children, namely learning remotely. According to research conducted by (Buli-Holmberg \& Jeyaprathaban, 2016), children with special needs need positive interactions as well as innovative and flexible activities that can meet the needs. Deaf children are 
one type of children with special needs, deaf children are children who experience loss or obstacles in hearing that cause child have difficulty in carrying out their daily lives (Haenudin, 2013). Meanwhile (Allyvia, 2018) said that deaf children are children who lose the ability to hear caused by the malfunction of some or all hearing devices so that they experience obstacles in communicating.

From the above opinion, it can be concluded that deaf children are children who lose some or all of their hearing skills so that they experience obstacles in communicating, therefore deaf children need adaptation in some aspects of their lives, including adaptation in education.

Like other children with special needs, deaf children need more attention in achieving optimal learning activities, especially in distance learning, deaf children need attractive innovators from the classroom teachers to foster a positive learning interest even from home. From the interviews of 10 classroom teachers with deaf children, they conveyed the most learning materials through videowall through WhatsApp application and for some reason have never tried to convey learning materials through applications such as zoom meeting or youtube. The previous research related to the use of distance learning media is research by (Bhatti et al., 2021) on the use of offline game applications to learn to know the language of deaf children who are converted into animated images. Furthermore (Grane \&Crescenzi-Lanna, 2021) explains that the use of some android applications is very helpful for deaf children in understanding language. The latest research by (Millett, 2021) conveys some tips in the application of zoom meetings so that they can be accessed by deaf children well.

From the explanation above, it is known that deaf children need positive innovation from the classroom teacher in the delivery of creative and fun distance learning materials, especially the use of remote applications that suit the needs of children, there are at least three smartphone applications that are popular in distance learning, among others, 1) Whatsapp Application, 2) Zoom Meeting Application and 3) Youtube Application. Therefore, researchers will conduct a study to find out what smartphone applications are most mastered that deaf children love in receiving distance learning materials. 


\section{METHODOLOGY}

This study uses descriptive analysis with case study methods. Case studies can be interpreted as intensive studies used to examine data in depth related to variables (Heale \&Twycross, 2018). In this study, researchers distributed a questionnaire containing a list of questions related to the mastery of smartphone applications as a means of distance learning in deaf children. This questionnaire is distributed and filled by deaf children in secondary school who are recorded as attending SLBB YRTRW Surakarta. The list of questions consists of aspects of knowledge and use of smartphone applications as a means of learning, as well as learning time that children like.

\section{RESULT AND DISCUSSION RESULT}

In the context of learning, strategies relate to approaches in delivering materials to learning activities. Learning strategies are also interpreted as patterns that teachers choose and use contextually, by student characteristics, school conditions, environment and learning objectives that have been formulated. The learning strategy consists of methods, techniques, and procedures that will ensure that the learners will achieve the learning objectives (Nasution, 2017). Based on other research according to (Pawlak, 2019), he revealed that learning strategies cover various aspects, namely, objectives, learning steps, methods, media, time, and assessment. And one aspect in achieving learning goals is learning media. The use of learning media aims to help students in understanding the subject matter, can also be used to improve the effectiveness of learning media used (Kustyarini et al., 2020).

Deaf children as one of the children with special needs who have barriers in communicating. In learning activities they need special handling. Some classroom teachers have expressed difficulty in providing appropriate learning media for deaf children and most say they do not have enough skills in technology mastery to serve deaf children in distance learning that relies on mastery of communication technology.

Based on the results of data collection through questionnaire stuffing by deaf children in high school at SLB-B YRTRW Surakarta, researchers found that there are three applications from smartphones that appear to be used by teachers and children in distance learning 
activities, namely through Whatsapp, Zoom Meeting, and Youtube applications.

The description of smartphone application mastery by deaf children in receiving distance learning materials is as follows:

Table 1. Data recapitulation mastery whatsapp application As a means of distance learning for deaf children

\begin{tabular}{clrcc}
\hline Num & Question & $\begin{array}{c}\text { Alternative } \\
\text { Answers }\end{array}$ & $\begin{array}{c}\text { Percentage } \\
\text { of } \\
\text { Answers }\end{array}$ \\
\hline 1 & Yes & No & "Yes" \\
\hline 2 & $\begin{array}{l}\text { Do you know the } \\
\text { Whatsapp app? }\end{array}$ & 38 & 0 & $100,00 \%$ \\
\hline $\begin{array}{l}\text { Do you have } \\
\text { whatsapp app on } \\
\text { smartphone? }\end{array}$ & 38 & 0 & $100,00 \%$ \\
\hline 3 & $\begin{array}{l}\text { Do you often use } \\
\text { Whatsapp App in } \\
\text { learning and } \\
\text { receiving } \\
\text { other information? }\end{array}$ & 36 & 2 & $94,74 \%$ \\
\hline
\end{tabular}

From Table 1 above, it can be seen that from 38 respondents in this case $100 \%$ high school deaf children revealed knowing, owning, and often using WhatsApp application as a means of communication and even receiving distance learning materials.

Table 2. Data recapitulation mastery zoom meeting application As a means of distance learning for deaf children

\begin{tabular}{clrrr}
\hline Num & \multicolumn{1}{c}{ Question } & $\begin{array}{r}\text { Alternative } \\
\text { Answers }\end{array}$ & $\begin{array}{c}\text { Percentage of } \\
\text { Answers } \\
\text { "Yes" }\end{array}$ \\
\hline 1 & $\begin{array}{l}\text { Do you know the } \\
\text { Zoom Meeting app? }\end{array}$ & 25 & 13 & $65,79 \%$ \\
\hline 2 & $\begin{array}{l}\text { Do you have the } \\
\text { Zoom Meeting app } \\
\text { on your Smartphone? }\end{array}$ & 9 & 29 & 23,68 \\
\hline 3 & $\begin{array}{l}\text { Do you often use the } \\
\text { Zoom Meeting App } \\
\text { to learn and receive } \\
\text { other information? }\end{array}$ & 0 & 38 & $0.00 \%$ \\
\hline
\end{tabular}

From Table 2 above, it can be seen that of the 38 respondents, in this case, $65.79 \%$ of middle school deaf children stated that they know the Zoom meeting application, then $23.68 \%$ have a Zoom Meeting application, but $0.00 \%$ of children who often use the Zoom Meeting application or all children have never used the Zoom Meeting application as a means of following distance learning.

Table 3. Recapitulation of youtube application mastery data as a means of distance learning for deaf children,

\begin{tabular}{|c|c|c|c|c|}
\hline \multirow[t]{2}{*}{ Num } & \multirow[t]{2}{*}{ Question } & \multicolumn{2}{|c|}{$\begin{array}{r}\text { Alternative } \\
\text { Answer }\end{array}$} & \multirow{2}{*}{ 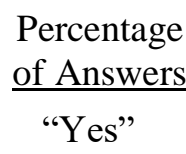 } \\
\hline & & Yes & No & \\
\hline 1 & $\begin{array}{l}\text { Do you know the } \\
\text { Youtube app? }\end{array}$ & 38 & 0 & $100,00 \%$ \\
\hline 2 & $\begin{array}{l}\text { Do you have } \\
\text { Smartphone? }\end{array}$ & 38 & 0 & $100,00 \%$ \\
\hline 3 & $\begin{array}{l}\text { Do you often use } \\
\text { Youtube } \\
\text { Application in } \\
\text { learning and } \\
\text { receiving other } \\
\text { information? }\end{array}$ & 38 & 0 & $100,00 \%$ \\
\hline
\end{tabular}


From Table 3 above, it can be seen that from 38 respondents in this case $100 \%$ high school deaf children revealed knowing, owning, and often using Youtube application as a means of receiving information.

Table 4. Recapitulation of learning time data that deaf children love most in online learning,

\begin{tabular}{|c|c|c|c|c|c|}
\hline \multirow[t]{2}{*}{ Num } & \multirow[t]{2}{*}{ Question } & \multicolumn{4}{|c|}{$\begin{array}{c}\text { Alternative } \\
\text { Answer }\end{array}$} \\
\hline & & Morning & day & night & free \\
\hline 1 & $\begin{array}{l}\text { When is the } \\
\text { preferred } \\
\text { time to learn } \\
\text { online? }\end{array}$ & 4 & 7 & 3 & 25 \\
\hline & $\begin{array}{l}\text { Percentage } \\
\text { of Answers }\end{array}$ & $10,53 \%$ & $\begin{array}{l}18, \\
42 \\
\%\end{array}$ & $\begin{array}{c}7,89 \\
\%\end{array}$ & $\begin{array}{l}65,7 \\
9 \%\end{array}$ \\
\hline
\end{tabular}

From Table 4 above, it can be seen that of the 38 respondents in this case high school deaf children $10.53 \%$ liked online learning in the morning, $18.42 \%$ liked online learning during the day, then $7.89 \%$ liked online learning in the afternoon and $65.79 \%$ liked online learning at night

\section{DISCUSSION}

The Covid-19 pandemic is still having a significant impact on education which has an impact on school closures (Van Lancker \&Parolin, 2020). This resulted in the emergence of policies on the application of distance learning systems or online learning. Changes in the online learning system greatly affect the quality of education including in Indonesia where both students and teachers are encouraged to be active in creating innovations in learning to think positively in the future to achieve the purpose of learning, namely behavior change. (Mansur, 2018).

Although distance learning activities in several developed countries have existed since before the Covid-19 pandemic (Sharma, 2016). Based on previous research conducted by (Agarwal \&Dewan, 2020) online learning needs to pay attention to several things, including lesson plans designed by online learning. In the lesson plan there must be a medium where it can be delivered through the help of online applications from both computers and smartphones. Similarly, deaf children in the world of education, where deaf children with hearing barriers have difficulty to follow distance learning, so there needs to be innovation from the class teacher in determining the right media as a learning tool.

According to research (Secora \&Emmorey, 2020) preferably the media 
used for deaf children is far from oral use. Similarly, research conducted by (Worster et al., 2018) which explains that in receiving information, children tunrungu more use visual ability to read information in the form of images or symbols.

Based on the description above, it can be concluded that the use of the right learning media for deaf children is to maximize visual ability through interesting media. As a tool in delivering lesson materials is one of them by utilizing applications from smartphones.

From the results of filling the questionnaire by 38 deaf children in high school above, it can be known the level of application mastery of semartphone in the form of Whatsapp Application as a means of communication used to receive distance learning materials is $94.74 \%$, the level of mastery of Zoom Meeting application from 38 deaf children in middle school level is recorded $0.00 \%$, then the mastery level of Youtube application in receiving information from 38 deaf children in secondary school level is $100.00 \%$. And the most preferred time for deaf children to learn is free, which is $65.79 \%$. So it can be concluded that the smartphone application that is most mastered by middle school deaf children in learning and receiving information is a Youtube application and the time that deaf children like in learning is free or unspecified.

The use of Youtube application is a new habit for all circles both children to adulthood let alone pandemic that urges everyone to limit activities outside the home, this application can be accessed anytime and anywhere as long as it is connected to the internet, even video content in it can also be downloaded into smartphones including learning videos. The learning using youtube application for children with special needs according to (Setiawati, 2020) can meet the needs of teachers in realizing the maximum teaching and learning process. Also, by learning using youtube application, children with special needs get a new experience in utilizing technology that can grow confidence (Jannah et al., 2020). The benefits of using youtube application in learning according to (Pratiwi \&Hapsari, 2020) in research on regular students in elementary school namely (1) the use of YouTube effectively as a medium of learning Indonesian language. YouTube as a stimulus helps formulate the material on which the question is based in a particular context. (3) YouTube 
makes it easy for students to work on easy, medium, and difficult questions.

\section{CONCLUSION}

Based on the results of the research and discussion described above, it can be concluded that the use of smartphone applications to help distance learning activities is very helpful for both teachers and students, including deaf children. Moreover, the use of youtube application that is being widely utilized for all circles from children to adults as a means of entertainment and a means of finding information, for that youtube application can be referred to as a source of learning millennials (Setiadi et al., 2019). Youtube application can load multisensory content, among others, able to load images and sounds that can be played anytime and anywhere.

The habit of using smartphone applications classified in social media can indirectly make its users access information and learn the information it accesses, so it is not surprising that nowadays language development and dissemination runs very quickly. This digital era marks that today society has become a modern society. (Kamhar \&Lestari, 2019). In learning youtube media becomes the highest in terms of use, especially for deaf children who have an interest in visual characters such as videos and images. In a study (Moghavvemi et al., 2018) found that YouTube is an effective tool that can improve the learning experience if the video is indeed relevant to the subject. It is also recommended that teachers be able to integrate YouTube into the classroom to benefit from the inherent advantages in the context of learning.

\section{REFERENCE}

Abidah, A., Hidaayatullaah, H. N., Simamora, R. M., Fehabutar, D., \& Mutakinati, L. (2020). The impact of COVID-19 to Indonesian Education and its Relation to the philosophy of "Merdeka Belajar." Studies in Philosophy of Science and Education, 1(1), 38-49.

Agarwal, M. S., \& Dewan, D. J. (2020). An Analysis of the Effectiveness of Online Learning in Colleges of Uttar Pradesh during the COVID 19 Lockdown. Journal of Xi'an University of Architecture \& Technology, ISSN, 1006-7930, 2957-2963.

Al-Balas, M., Al-Balas, H. I., Jaber, H. 
M., Obeidat, K., Al-Balas, H., Aborajooh, E. A., Al-Taher, R., \& Al-Balas, B. (2020). Distance learning in clinical medical education amid COVID-19. pandemic in Jordan: current situation, challenges, and perspectives. BMC Medical Education, 20(1), 1-7.

Allyvia, R. N. (2018). Motivasi Berprestasi Anak Tunarungu. Fakultas Psikologi. Universitas Ahmad Dahlan Yogyakarta.

Beneke, A. J. (2020). Review of Justice on both sides: Transforming education through restorative justice. Education Review, 27.

Bhatti, Z., Muhammad, F., Malik, H. A. M., Hussain, M., Chandio, H., Channa, S., \& Mahar, Z. (2021). Text to Animation for Sign Language of Urdu and Sindhi. IKSP Journal of Emerging Trends in Basic and Applied Sciences, 1(1).

Buli-Holmberg, J., \& Jeyaprathaban, S. (2016). Effective practice in inclusive and special needs education. International Journal of Special Education, 31(1), 119-134.

Diningrat, S. W. M., Nindya, M. A., \& Salwa, S. (2020). EMERGENCY ONLINE TEACHING: EARLY
CHILDHOOD EDUCATION LECTURER PERCEPTION OF BARRIER AND

PEDAGOGICAL COMPETENCY. Jurnal Cakrawala Pendidikan, 39(3). Grane, M., \& Crescenzi-Lanna, L. (2021). Improving the Interaction Design of Apps for Children with Special Educational Needs. Journal of Educational Multimedia and Hypermedia, 30(2), 139-164.

Haenudin, H. (2013). Pendidikan anak berkebutuhan khusus tunarungu. Jakarta: PT Luxima Metro Media.

Heale, R., \& Twycross, A. (2018). What is a case study? Royal College of Nursing. Jannah, R. N., Wulandari, N. L., \& Budi, S. (2020). Pengalaman Belajar Daring Siswa Berkebutuhan Khusus pada Pandemi COVID-19 di SD Inklusif. ELEMENTARY: Islamic Teacher Journal, 8(2), 359-376.

Kamhar, M. Y., \& Lestari, E. (2019). Pemanfaat Sosial Media Youtube Sebagai Media Pembelajaran Bahasa Indonesia DI Perguruan Tinggi. Inteligensi: Jurnal Ilmu Pendidikan, 1(2), 1-7.

Kustyarini, K., Utami, S., \& Koesmijati, E. (2020). THE IMPORTANCE OF INTERACTIVE LEARNING 
MEDIA IN A NEW CIVILIZATION

ERA. European Journal of Open Education and E-Learning Studies, $5(2)$.

Mansur, R. (2018). Belajar jalan perubahan menuju kemajuan.

Vicratina: Jurnal Pendidikan Islam, 3(1).

Millett, P. (2021). Tips for making Zoom accessible for students who are deaf or hard of hearing (powerpoint slides).

Moghavvemi, S., Sulaiman, A., Jaafar, N. I., \& Kasem, N. (2018). Social media as a complementary learning tool for teaching and learning: The case of youtube. The International Journal of Management Education, 16(1), $37-42$.

Nasution, W. N. (2017). Strategi pembelajaran.

Ogbonna, C. G., Ibezim, N. E., \& Obi, C. A. (2019). Synchronous versus asynchronous e-learning in teaching word processing: An experimental approach. South African Journal of Education, 39(2).

Pawlak, M. (2019). Investigating language learning strategies: Prospects, pitfalls and challenges. Language Teaching

Research,
1362168819876156.

Pratiwi, B., \& Hapsari, K. P. (2020). Kemampuan Berpikir Tingkat Tinggi Dalam Pemanfaatan YouTube Sebagai Media Pembelajaran Bahasa Indonesia. Jurnal Ilmiah Sekolah Dasar, 4(2), 282-289.

Prawiyogi, A. G., Purwanugraha, A., Fakhry, G., \& Firmansyah, M. (2020). Efektivitas Pembelajaran Jarak Jauh Terhadap Pembelajaran Siswa di SDIT Cendekia Purwakarta. Jurnal Pendidikan Dasar, 11(1), 94101.

Putri, R. S., Purwanto, A., Pramono, R., Asbari, M., Wijayanti, L. M., \& Hyun, C. C. (2020). Impact of the COVID-19 pandemic on online home learning: An explorative study of primary schools in Indonesia. International Journal of Advanced Science and Technology, 29(5), 4809-4818.

Salama, R., Uzunboylu, H., \& Alkaddah, B. (2020). Distance learning system, learning programming languages by using mobile applications. New Trends and Issues Proceedings on Humanities and Social Sciences, 7(2), 23-47. 
Secora, K., \& Emmorey, K. (2020). Visual-Spatial Perspective-Taking in Spatial Scenes and in American Sign Language. The Journal of Deaf Studies and Deaf Education, 25(4), 447-456.

Setiadi, E. F., Azmi, A., \& Indrawadi, J. (2019). Youtube Sebagai Sumber Belajar Generasi Milenial. Journal of Civic Education, 2(3), 313-323.

Setiawati, S. D. (2020). MOTIF PENGGUNAAN MEDIA YOUTUBE SEBAGAI MEDIA PEMBELAJARAN DIKALANGAN GURU ABK SLBN CICENDO KOTA BANDUNG. VISIONER, $2(2$ Desember), 288-297.

Sharma, R. (2016). Effect of school and home environments on creativity of children. MIER Journal of Educational Studies, Trends and Practices, 1(2).

Van Lancker, W., \& Parolin, Z. (2020). COVID-19, school closures, and child poverty: a social crisis in the making. The Lancet Public Health, 5(5), e243-e244.

Viner, R. M., Russell, S. J., Croker, H., Packer, J., Ward, J., Stansfield, C., Mytton, O., Bonell, C., \& Booy, R. (2020). School closure and management practices during coronavirus outbreaks including COVID-19: a rapid systematic review. The Lancet Child \& Adolescent Health, 4(5), 397-404.

Worster, E., Pimperton, H., Ralph-Lewis, A., Monroy, L., Hulme, C., \& MacSweeney, M. (2018). Eye movements during visual speech perception in deaf and hearing children. Language Learning, 68, 159-179.

Zili, A. H. A., Kharis, S. A. A., \& Lestari, D. (2021). Peramalan Tingkat Kematian Indonesia Akibat Covid-19 Menggunakan Model Arima. Jurnal Indonesia Sosial Sains, 2(1), 1-8. 